\title{
Common fixed point and best approximation results for subcompatible mappings in hyperbolic ordered metric spaces
}

\section{SAVITA RATHEE and REETU}

\section{ABSTRACT.}

In the present paper we establish a common fixed point theorem and apply it to find new best approximation results for ordered subcompatible mappings in the hyperbolic ordered metric space. Our results unify, generalize and complement various known results.

\section{REFERENCES}

[1] Abbas, M., Khamsi, M. A. and Khan, A. R., Common fixed point and invariant approximation in hyperbolic ordered metric spaces, Fixed Point Theory and Appl., 25 (2011), 1-14

[2] Akbar, F. and Khan, A. R., Common fixed point and approximation results for noncommuting maps on locally convex spaces, Fixed Point Theory and Appl., 2009, (2009), 14 pages

[3] Altun, I., Damjanovic, B. and Djoric, D., Fixed point and common fixed point theorems on ordered cone metric spaces, Appl. Math. Lett., 23 (2010), 310-316

[4] Beg, I., Sahu, D. R. and Diwan, S. D., Approximation of fixed points of uniformly R-subweakly commuting mappings, J. Math. Anal. Appl., 324 (2006), 1105-1114

[5] Doric, D., Common fixed point for generalized ( $\psi, \varphi$ )-weak contractions, Appl. Math. Lett., $22 \quad(2009)$, 1896-1900

[6] Hussain, N. and Rhoades, B. E., $C_{q}$-commuting maps and invariant approximations, Fixed Point Theory Appl., 9 (2006), 9 pp.

[7] Hussain, N. and Jungck, G., Common fixed point and invariant approximation results for noncommuting generalized (f, g)- nonexpansive map., J. Math. Anal. Appl., 321 (2006), 851-861

[8] Khamsi, M. A., KKM and Ky Fan theorems in hyperconvex metric spaces, J. Math. Anal. Appl., 204 (1996), 298-306

[9] Khamsi, M. A. and Khan, A. R., Inequalities in metric spaces with applications, Nonlinear Anal., 74 (2011), 4036-4045

[10] Khan, A. R., Fukhar-ud-din, H. and Domlo, A. A., Approximating fixed points of some maps in uniformly convex metric spaces, Fixed Point Theory Appl., 11 (2010), (Article ID 385986)

[11] Nashine, H. K. and Imdad, M., Common fixed points and best approximations for subcompatible mappings in convex metric spaces, Math. Commun., 16 (2011), $1-12$

[12] Nieto, J. J. and Lopez, R. R., Contractive mapping theorems in partially ordered sets and applications to ordinary differential equations, Order, 22 (2005), 223-239

[13] Park, S., Fixed point theorems in hyperconvex metric spaces, Nonlinear Anal., 37 (1999), 467-472

[14] Radenović, S. and Kadelburg, Z., Generalized weak contractions in partially ordered metric spaces, Comput. Math. Appl., 60 (2010), 1776-1783

[15] Ran, A. C. M. and Reurings, M. C. B., A fixed point theorem in partially ordered sets and some application to matrix equations, Proc. Amer. Math. Soc., 132 (2004), 1435-1443

[16] Rathee, S. and Kumar, A., Some common fixed point results for modified subcompatible maps and related invariant approximation results, Abstract and Applied Analysis, 2014 (2014), 9 pages

[17] Saadati, R. and Vaezpour, S. M., Monotone generalized weak contractions in partially ordered metric spaces, Fixed Point Theory, 11 (2010), 375-382

[18] Saadati, R. and Vaezpour, S. M., Vetro, P. and Rhoades, B. E., Fixed point theorems in generalized partially ordered G-metric spaces, Math. Comp. Model., 52 (2010), 797-801

[19] Takahashi, W. A., Convexity in metric space and nonexpansive mappings, Kodai Math. Sem. Rep., 22 (1970), 142-149

DEPARTMENT OF MATHEMATICS

MAHARSHI DAYANAND UNIVERSITY

ROHTAK-124001, INDIA

E-mail address: dr.savitarathee@gmail.com

\section{DEPARTMENT OF MATHEMATICS}

VAISH COLLEGE

ROHTAK-124001, INDIA

E-mail address: singhal.ritu.mathegmail.com 